\section{DISCRIMINATION OF EXTRACTED ANIMAL FATS USING LASER-INDUCED BREAKDOWN SPECTROSCOPY ASSISTED WITH PRINCIPAL COMPONENT ANALYSIS}

\author{
Nur Syaida Hanasila, Raja Kamarulzaman Raja Ibrahim*, Maisarah \\ Duralima, Husni Hani Jameela Sapingic
}

aDepartment of Physics, Faculty of Science, Universiti Teknologi Malaysia, 81310 UTM Johor Bahru, Johor, Malaysia

bLaser Centre, Ibnu Sina Institute for Scientific and Industrial Reseach (ISI-SIR), Universiti Teknologi Malaysia 81310 UTM Johor Bahru, Johor, Malaysia

cDepartment of Electronic System Engineering, Malaysia-Japan International Institute of Technology (MJIIT), Universiti Teknologi Malaysia, Kuala Lumpur, Jalan Sultan Yahya Petra (Jalan Semarak), 54100 Kuala Lumpur, Malaysia
Article history

Received

12 August 2019

Received in revised form

2 May 2020

Accepted

14 May 2020

Published online

22 June 2020

*Corresponding author rkamarulzaman@utm.my

\section{Graphical abstract Abstract}
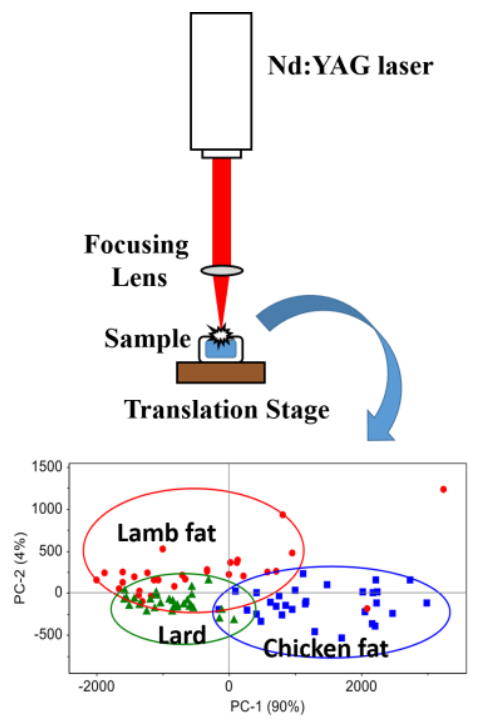

This study focuses on the discrimination of extracted animal fats in liquid form using laser induced breakdown spectroscopy (LIBS) technique assisted with principal component analysis (PCA). The interaction of laser and liquid sample produces liquid splashing due to strong shock wave effect and subsequently generates lower intensity of LIBS signals. LIBS difficulties in liquid are resolved using paper substrate to enhance LIBS emission intensity. Laser pulse from Q-switched Nd:YAG laser with energy of $220 \mathrm{~mJ}$ and frequency of $1 \mathrm{~Hz}$ was used to ablate extracted animal fats. The obtained LIBS spectra of extracted animal fats were further evaluated using PCA. LIBS spectra are compressed and visualised as data points in the score plot of PCA. PCA results demonstrated that data points from different extracted animal fats were clustered separately in the score plot with variance greater than $90 \%$. The findings show LIBS system assisted with PCA was capable to differentiate various extracted animal fats.

Keywords: LIBS, PCA, animal fats, plasma, liquid ablation

Abstrak

Kajian ini memberi tumpuan kepada diskriminasi ekstrak lemak haiwan dalam bentuk cecair menggunakan teknik laser teraruh pecahan spektroskopi (LIBS) dibantu dengan analisis komponen utama (PCA). Interaksi antara laser dan sampel cecair menghasilkan percikan cecair yang disebabkan oleh kesan gelombang kejutan yang kuat dan seterusnya menghasilkan isyarat LIBS yang lemah. Kesukaran LIBS dalam cecair diselesaikan menggunakan kertas substrat untuk meningkatkan intensiti isyarat LIBS. Denyutan laser dari laser Q-switched Nd:YAG yang mempunyai tenaga $220 \mathrm{~mJ}$ dan frekuensi $1 \mathrm{~Hz}$ telah digunakan untuk mengablasi ekstrak lemak haiwan. Isyarat LIBS ekstrak lemak haiwan yang diperolehi dinilai dengan lebih lanjut menggunakan PCA. Isyarat LIBS dimampatkan dan digambarkan sebagai titik data dalam plot skor. Hasil PCA menunjukkan bahawa titik data dari pelbagai ekstrak lemak haiwan berkumpul secara berasingan di dalam plot skor dengan varian lebih besar daripada $90 \%$. Penemuan menunjukkan sistem LIBS yang dibantu dengan PCA mampu membezakan pelbagai ekstrak lemak haiwan.

Kata kunci: LIBS, PCA, lemak haiwan, plasma, ablasi cecair
\end{abstract}




\subsection{INTRODUCTION}

The importance of animal fats in the industries is largely employed to produce soaps, candles and biodiesel [1]. In the food industry, animal fats are mixed with vegetable oils in the production of shortening which mostly used for baking cake [2]. The addition of animal fat in foods is to improve the texture and flavor of the foods. The examples of animal fat are chicken fat, beef fat, lamb fat and lard [3].

Raw animal fat obtained from the market is not purely fat as it might consist of meat tissue, connective tissue, blood, as well as water content. To acquire the pure fat, it needs a preparation such as heating and filtering process [4]. Physically, the heating process produced animal fats in liquid form and solidified at ambient temperature. The animal fat with high content of saturated fat is easily turned into solid at room temperature. Meanwhile, chicken fat and lard which have lower content of saturated fat take longer time to solidify [3].

For Muslims and Hindus, they are forbidden to consume food or any products containing lard due to religious concerns [5]. Thus, a reliable and effective technique for the animal fat analysis is important in food industry to verify the ingredients of food products. In previous works, infrared spectroscopy [6], Raman spectroscopy [7] and gas chromatography [8] techniques were employed to discriminate various animal fats. However most of these techniques were time consuming with complex procedures. As opposed to the mentioned techniques, Laser induced breakdown spectroscopy (LIBS) setup is simpler, allow for simultaneous elemental measurement and requires a small amount of sample.

LIBS is a sensitive optical technique based on laser technology for elemental analysis of solid, liquid and gaseous. In LIBS system, a pulsed laser beam is focused on material surface to produce characteristic light. Capturing of this emission on a spectrometer provides the LIBS spectrum [9]. Studies on elemental composition in various animal tissues using LIBS application have achieved a great attention among researchers. For example, LIBS was employed to discriminate pork, beef and chicken meats with multivariate analysis of principal component analysis (PCA). Meat tissues were successfully discriminated into three clusters in PCA score plot with $83.37 \%$ of variance [9]. The differentiation of nerve and fat tissues in pig head was investigated using LIBS combined with statistical analysis of PCA, Linear Discriminant Analysis (LDA) and Receiver Operating Characteristics (ROC). In this work, the author managed to reduce the number of variables using PCA and classified nerve and fat tissues of pig head using LDA and ROC [10]. The prominent elements found in animal tissues were carbon (C), hydrogen $(\mathrm{H})$, oxygen $(\mathrm{O})$, chlorine $(\mathrm{Cl})$, sodium (Na), potassium (K), nitrogen (N), calcium (Ca), magnesium (Mg) and zinc (Zn) [9-11].

From the literatures, most of LIBS applications were investigated on animal soft tissues [9-13] instead of different type of animal fats in liquid form. The interaction between laser beam and liquid samples generated splashing and shockwave effect [14]. These problems affected the focal length of the exciting laser beam and produced a poor signal of plasma [1415]. Therefore, this study was conducted to investigate the effectiveness of ungated LIBS system assisted with statistical method of PCA to discriminate extracted chicken fat, lamb fat and lard in liquid form. A white paper was used as the substrate to improve the performance of laser ablation for the animal fats in liquid form.

\subsection{METHODOLOGY}

\subsection{Samples Preparation}

Extracted animal fats were prepared according to previous study [19]. Raw chicken fat, lamb fat and lard were cleaned from meat tissues and blood. Deionized water was used to wash animal fats surface. Cleaned animal fats were cut into small pieces and heated in oven for 3 hours with the temperature of $100{ }^{\circ} \mathrm{C}$ to obtain liquid form of animal fats or extracted animal fats. The obtained extracted animal fats were filtered using muslin cloth to remove any solid impurities. A droplet of extracted animal fats $(0.5 \mathrm{ml} /$ droplet) was drew up and dispensed onto white paper using a pipette. Wet papers with extracted animal fats were left in a clean air atmosphere for about 20 minutes to affirm that the extracted animal fat was homogeneously expanded and absorbed in the paper before ablated with laser beam.

\subsection{LIBS Instrumentation}

A Q-Switched Nd:YAG laser (Tattoo Removal Laser System, GSD-903) which delivered a pulse energy of $220 \mathrm{~mJ}$ with a pulse duration of $8 \mathrm{~ns}$ at a wavelength of $1064 \mathrm{~nm}$ was utilised as a laser source. The laser beam at a repetition rate of $1 \mathrm{~Hz}$ was focused onto the sample surface by convex lens with a focal length of $50 \mathrm{~mm}$. The samples were placed on the translation stage at the focal point of the focusing lens. The plasma formed on the sample surface was then collected by optical fiber and delivered to a spectrometer (USB4000, spectral range: 181.79-946.08 nm, resolution: 0.1-10.0 nm FWHM, Ocean Optics, USA). The respective spectrum was obtained using Spectrasuite software installed in personal computer. For each sample, 30 measurements were taken at different spots. Thus, a total of 90 LIBS spectra were collected from fat samples. All analysis described in this study were based on these 90 LIBS spectra. The schematic diagram of ungated LIBS experimental setup for ablation process of extracted animal fats is shown in Figure 1. 


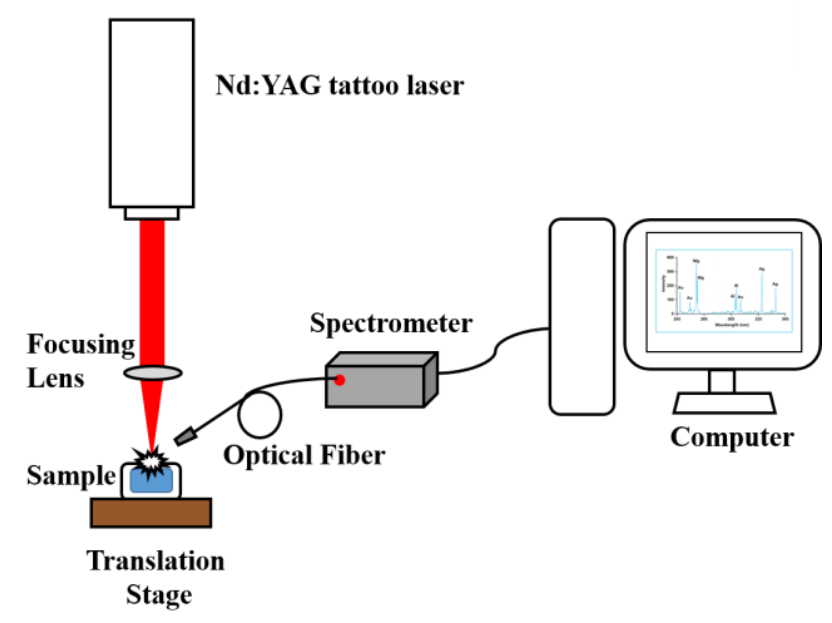

Figure 1 An ungated LIBS experimental setup for ablation process of extracted animal fats

\subsection{Data Analysis}

LIBS spectrum of extracted chicken fat, lamb fat and lard were re-plotted and the emission lines of elements were identified according to National Institute of Standards and Technology (NIST) atomic spectra database and compared to the literature. All collected LIBS spectra of extracted animal fats were further evaluated using PCA in Unscrambler $X$ software (v10.3, CAMO, Oslo, Norway). LIBS spectra of extracted animal fats were visualised in the score plot of PCA in 2 and 3 dimensions (2D and 3D) displayed by PC 1, PC 2 and PC 3 that has higher variance of spectral information. PCA analysis was performed on full spectra and specific range of wavelength according to selected elements in LIBS spectrum of extracted animal fats. The selected elements are emission lines from $\mathrm{Ca}, \mathrm{Mg}$ and $\mathrm{Na}$ in the obtained LIBS spectra of extracted animal fats.

\subsection{RESULTS AND DISCUSSION}

LIBS spectrum of extracted chicken fat, lamb fat and lard are depicted in Figure 2 (a), (b) and (c) which show emission lines emitted from interaction between laser beam and samples. These emission lines were associated with elements presence in extracted animal fats as given in Table 1.
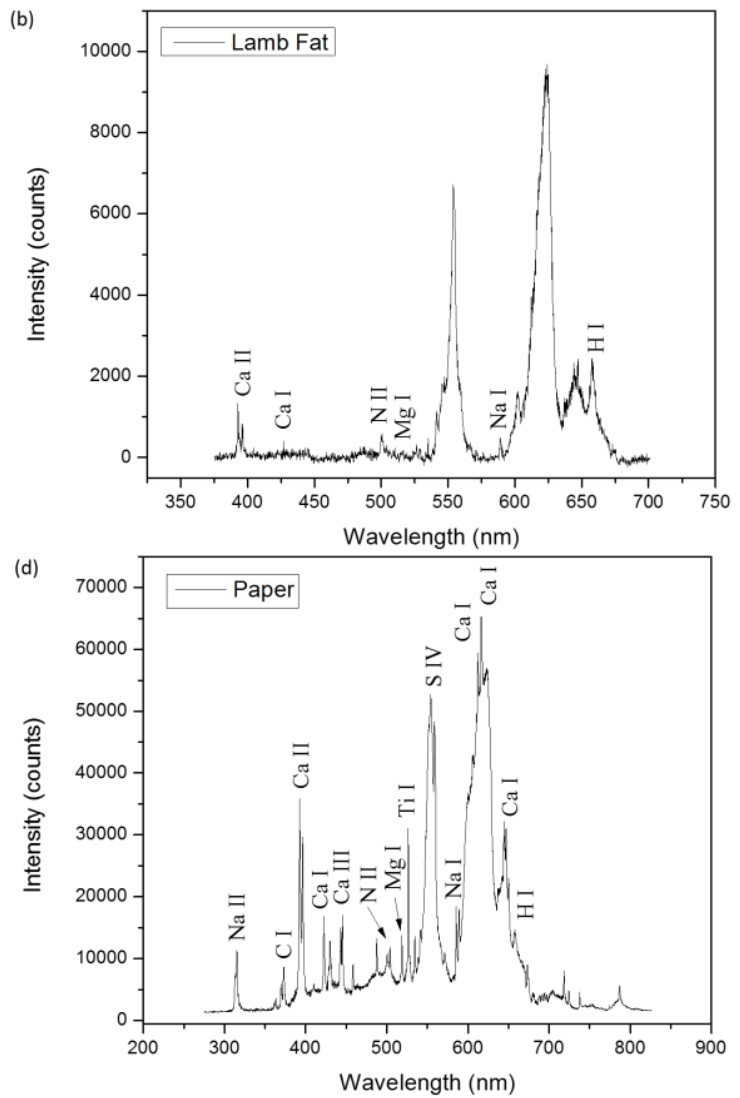

Figure 2 LIBS spectrum of extracted (a) chicken fat, (b) lamb fat and (c) lard with (d) LIBS spectrum of a paper substrate 
Table 1 The elements according to NIST atomic spectra database detected in LIBS spectra of extracted animal fats and chosen wavelengths for PCA

\begin{tabular}{|c|c|c|}
\hline $\begin{array}{l}\text { Observed } \\
\text { wavelength } \\
(\mathrm{nm})\end{array}$ & $\begin{array}{l}\text { Elements according } \\
\text { to NIST atomic } \\
\text { spectral database }\end{array}$ & $\begin{array}{l}\text { Wavelength used in } \\
\text { PCA (nm) }\end{array}$ \\
\hline 392.99 & Ca II (393.36 nm) & $390-400$ \\
\hline 396.38 & Ca II (396.84 nm) & $390-400$ \\
\hline 422.39 & Cal (422.67 nm) & $420-430$ \\
\hline 518.06 & $M g \mid(518.36 \mathrm{~nm})$ & $510-520$ \\
\hline 588.49 & $\mathrm{NaI}$ (588.99 nm) & $585-595$ \\
\hline 612.18 & $\mathrm{CaI}(612.22 \mathrm{~nm})$ & $600-659$ \\
\hline 616.31 & $\mathrm{CaI}(616.22 \mathrm{~nm})$ & $600-659$ \\
\hline 644.42 & $\mathrm{CaI}(643.91 \mathrm{~nm})$ & $600-659$ \\
\hline 646.78 & $\mathrm{CaI}(646.26 \mathrm{~nm})$ & $600-659$ \\
\hline
\end{tabular}

There was a slight variation between observed wavelength and wavelength from NIST atomic spectral database due to spectral shift in a spectrometer. The spectrum of the samples in Figure 2 was randomly chosen from collected LIBS spectra. LIBS spectrum of different extracted animal fats look similar to each other since they have emission lines at same wavelength but with different intensity. The intensity of emission lines explained the concentration of elements in different extracted animal fats [9]. From Figure 1, the dominant elements presence in extracted chicken fat, lamb fat and lard are calcium (Ca), sodium ( $\mathrm{Na}$ ), magnesium $(\mathrm{Mg})$, hydrogen $(\mathrm{H})$ and nitrogen $(\mathrm{N})$ which is parallel data with the literature [16]. The emission lines of $\mathrm{H}$ and $\mathrm{N}$ might be caused by $\mathrm{H}^{2}$ and $\mathrm{N}^{2}$ in the air since the experiment was conducted in open air [17]. Figure 2 (d) shows LIBS spectrum of paper. The broad peaks at $600-650 \mathrm{~nm}$ are convoluted by a few emission lines of Ca I. In the LIBS spectra of extracted animal fats, this broad peak looks like a single peak.

According to Bellof et al., the major elements of lamb fat are calcium, magnesium, sodium, potassium and phosphorus. There are only small amount of magnesium and calcium was found in lamb fat compared to sodium, potassium and phosphorus that has a higher amount [16]. The emission lines of sodium were reported stronger compared to magnesium and calcium in fat tissue of pig head [10]. In this study, the emission lines of $\mathrm{Ca}$ and $\mathrm{Na}$ were found to have higher intensity compared to $\mathrm{Mg}$ lines in LIBS spectra of extracted animal fats.

From the interpretation in Figure 2 (a), (b) and (c), the intensity of $\mathrm{Ca}$ I, Ca II, Mg I, Na I and broad peak in LIBS spectrum was varied among extracted animal fats. It was difficult to detect the variation for these emission lines of 90 LIBS spectra collected in this study and would be more appropriate to use multivariate data analysis such as PCA. In this study, PCA was used to visualise 30 LIBS spectra of each extracted animal fat in the score plot to find hidden pattern in the spectra. PCA was run on the full spectra and selected wavelength based on dominant elements presence in extracted animal fats. The chosen wavelengths for PCA are listed in Table 1. It is important to remove highly unnecessary variables and choose the main important lines of elements for multivariate analysis such as by chosen the emission lines with high signalto-noise ratio [17]. Hence, wavelength in the range of $390-400 \mathrm{~nm}, 420-430 \mathrm{~nm}, 510-520 \mathrm{~nm}, 585-595 \mathrm{~nm}$ and 600-650 nm were selected to develop PCA score plots.

The score plots of extracted chicken fat, lamb fat and lard for full spectrum (182-946 nm) and selected wavelengths as listed in Table 1 are depicted in Figure $3(\mathrm{a}-\mathrm{g})$ in 2D formed. Data points in 2D score plot are visualised using PC 1 and PC 2 which carry variance of spectral information greater than $90 \%$. One LIBS spectrum is visualised as one dot or one data point in the score plot [18]. A circle shape is a cluster of data points of each extracted animal fat. The score plots of extracted animal fats for wavelength of 182-946 nm, $390-400 \mathrm{~nm}, 420-430 \mathrm{~nm}, 510-520 \mathrm{~nm}, 585-595 \mathrm{~nm}$ and 600-659 nm are shown in Figure 3 (a), (b), (c), (d) (e) and (f) respectively.

Results revealed that the data points of extracted chicken fat and lard were differentiated in the score plot at wavelength of $182-946 \mathrm{~nm}$ and $600-659 \mathrm{~nm}$ in Figure $3(a)$ and (f) respectively. Some data points of extracted lamb fat were scattered into the cluster of extracted chicken fat and lard. Meanwhile, data points of extracted chicken fat and lamb fat were distinguished in the score plot at wavelength of 585$595 \mathrm{~nm}$ in Figure 3 (e). Most data points of extracted lard cannot be differentiated from the cluster of extracted lamb fat in this score plot.

Interestingly, data points of extracted chicken fat, lamb fat and lard were mostly distinguished in the score plots using wavelength of 390-400 nm, 420-430 $\mathrm{nm}$ and $510-520 \mathrm{~nm}$ as shown in Figure $3(\mathrm{~b}-\mathrm{d})$. This is due to different intensity of $\mathrm{Ca} \mathrm{I}, \mathrm{Ca} \|$ and $\mathrm{Mg} \mathrm{I}$ emission lines in LIBS spectra of the samples. Thus, one more score plot has been developed which combined wavelength of $390-400 \mathrm{~nm}, 420-430 \mathrm{~nm}$ and $510-520 \mathrm{~nm}$. The score plots of the combination of these wavelengths in 2D and 3D formed are shown in Figure 3 (g) and (h) respectively. The cluster of extracted chicken fat, lamb fat and lard were clearly distinguished in 3D compared to 2D score plot. In previous study, the discrimination of extracted animal fats has been achieved using freezing methods coupled with the ungated LIBS system and PCA approach [19]. A good discrimination of extracted chicken fat, beef fat, lamb fat and lard was obtained using 3D PCA score plot. 
(a)

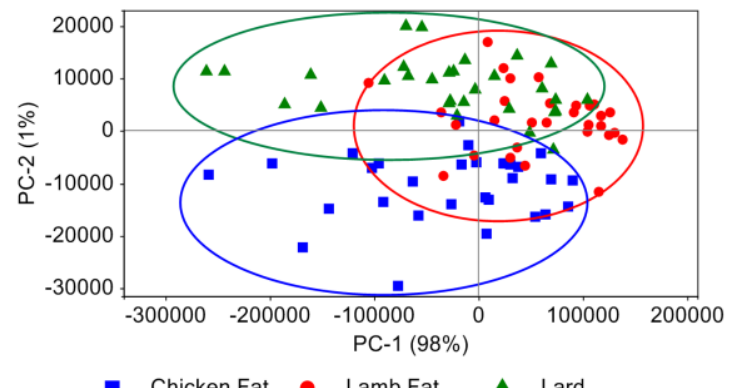

(c)

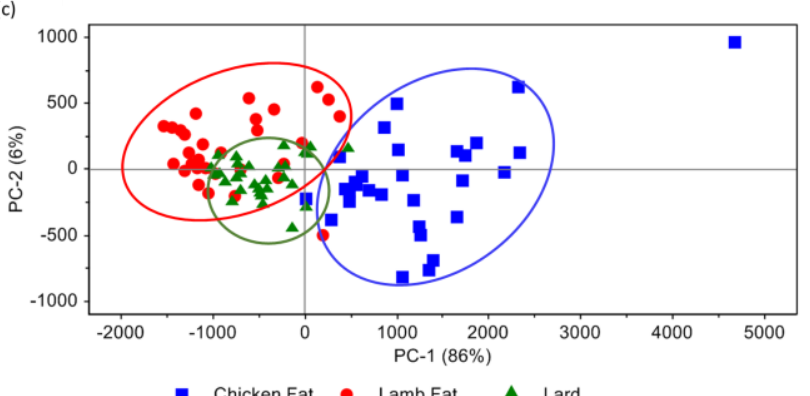

(e)

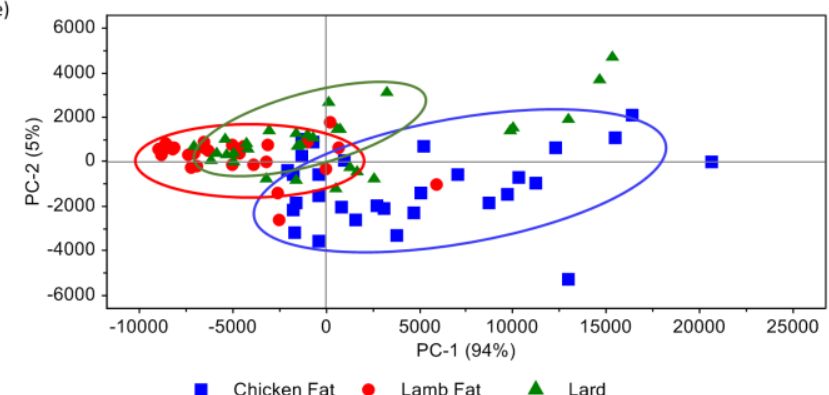

(g)

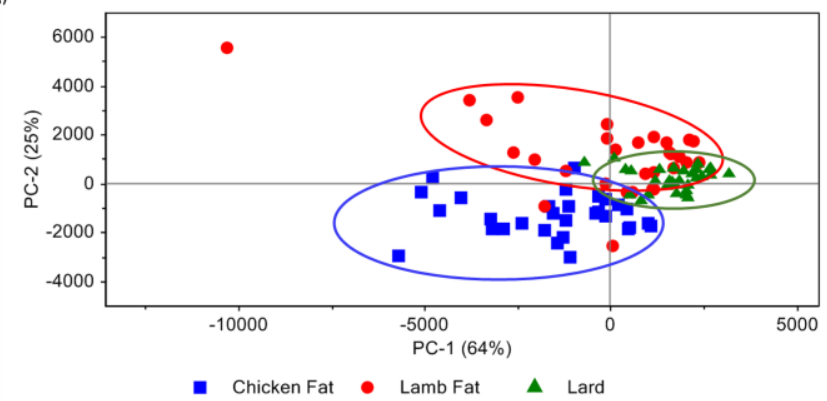

(b)

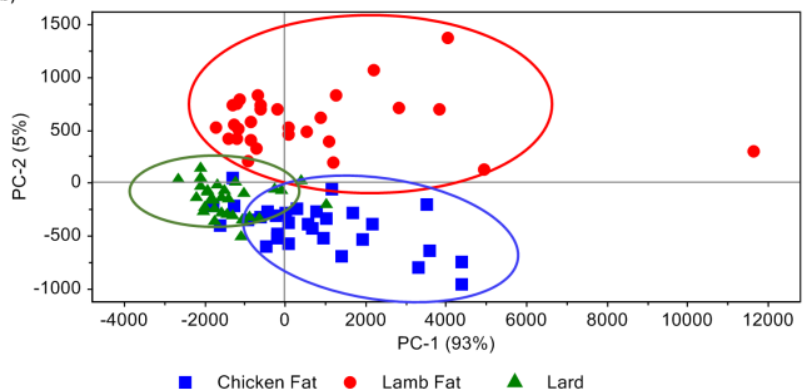

(d)

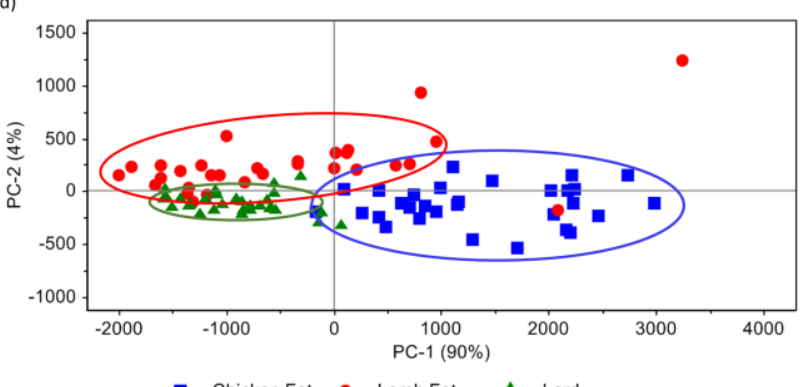

- Chicken Fat $\bullet$ Lamb Fat $\Delta$ Lard

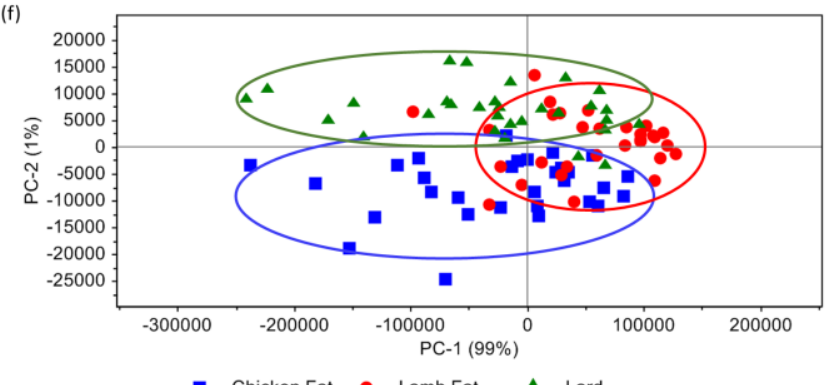

(h)

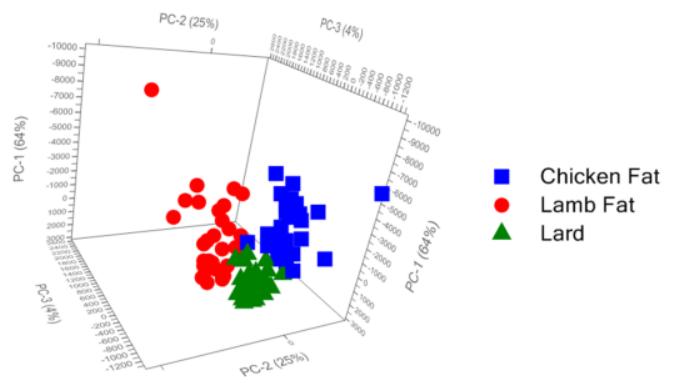

Figure 3 The score plots of extracted animal fats for wavelength of (a) 182-946 nm, (b) $390-400 \mathrm{~nm}$, (c) 420-430 nm, (d) $510-520$ $\mathrm{nm}$, (e) 585-595 nm, (f) $600-659 \mathrm{~nm}$ and combination wavelengths of $390-400 \mathrm{~nm}, 420-430 \mathrm{~nm}$ and $510-520 \mathrm{~nm}$ in (g) $2 \mathrm{D}$ and (h) 3D

\subsection{CONCLUSION}

In this study, the ungated LIBS system assisted with PCA approach have been developed and tested to differentiate various extracted animal fats in liquid form. The performance of liquid ablation was improved using white paper substrate. The findings from PCA shown that the data points of extracted chicken fat, lamb fat and lard were differentiated using wavelengths of $390-400 \mathrm{~nm}, 420-430 \mathrm{~nm}$ and $510-520 \mathrm{~nm}$ in 3D score plot. Thus, the ungated LIBS technique assisted with PCA approach was capable to discriminate extracted chicken fat, lamb fat and lard. 


\section{Acknowledgement}

Authors are thankful to Ministry of Education Malaysia and Universiti Teknologi Malaysia for financial supports through Fundamental Research Grant Scheme FRGS (4F869), Research University Grant Tier $1 \quad(13 \mathrm{H} 67)$ and Research University Grant Fundamental Research (20H97).

\section{References}

[1] Smith, S. B., \& Smith, D. R. 2015. Fats: Production and Uses of Animal Fats. In Caballero, B., Finglas, P. M., \& Toldrá, F. (Ed.). Encyclopedia of Food and Health. Oxford, UK: Elsevier Ltd. 604-608.

DOI: https://doi.org/10.1016/B978-0-12-384947-2.00273-7.

[2] Syahariza, Z. A., Che Man, Y. B., Selamat J., and Bakar, J. 2005. Detection of Lard Adulteration in Cake Formulation by Fourier Transform Infrared (FTIR) Spectroscopy. Food Chemistry. 92: 365-371. DOI: https://doi.org/10.1016/j.foodchem.2004.10.039.

[3] Oroian F. C., and Petrescu-Mag, I.V. 2017. Old and New Perspectives of Using Pork Fat, Porcine Research. 7(1): 10-16.

[4] Che Man, Y. B., Marina, A. M., Rohman, A., Al-Kahtani, H. A., and Norazura, O. 2014. A Fourier Transform Infrared Spectroscopy Method for Analysis of Palm Oil Adulterated with Lard in Pre-fried French Fries. International Journal of Food Properties. 17: 354-362. DOI: https://doi.org/10.1080/10942912.2011.631254.

[5] Kwon, D. Y., and Tamang, J. P. 2015. Religious Ethnic Foods. Journal of Ethnic Foods. 2: 45-46.

DOI: https://doi.org/10.1016/j.jef.2015.05.001.

[6] Lingzhi, X., Fei, G., Zengling, Y., Lujia, H., and Xian, L. 2016. Discriminant Analysis of Terrestrial Animal Fat and Oil Adulteration in Fish Oil by Infrared Spectroscopy. International Journal of Agricultural and Biological Engineering. 9(13): 179-185.

[7] Lee, J., Park, J., Mun, H., Shim, W., Lim, S., and Kim, M. 2018. Quantitative Analysis of Lard in Animal Fat Mixture Using Visible Raman Spectroscopy. Food Chemistry. 254: 109-114.

DOI: https://doi.org/10.1016/j.foodchem.2018.01.185.

[8] Nizar, N. N. A., Marikkar, J. M. N., and Hashim, D. M. 2013. Differentiation of Lard, Chicken Fat, Beef Fat and Mutton Fat by GCMS and EA-IRMS Techniques. Journal of Oleo Science. 62(7): 459-464.

DOI: https://doi.org/10.5650/jos.62.459.

[9] Bilge, G., Velioglu, H. M., Sezer, B., Eseller, K. E., and Boyaci, I. H. 2016. Identification of Meat Species by Using Laser-Induced Breakdown Spectroscopy. Meat Science. 119: 118-122.

DOl: https://doi.org/10.1016/j.meatsci.2016.04.035.

[10] Mehari, F., Rohde, M., Kanawade, R., Knipfer, C., Adler, W., Stelzle, F. and Schmidt, M. 2016. Investigation of the
Differentiation of Ex Vivo Nerve and Fat Tissues Using Laser-induced Breakdown Spectroscopy (LIBS): Prospects for Tissue-specific Laser Surgery. Journal of Biophotonics. 9(10): 1021-1032. DOI: https://doi.org/10.1002/jbio.201500256.

[11] Kanawade, R., Mehari, F. Knipfer, C., Rohde, M. Tangermann-Gerk, K., Schmidt, M., and Stelzle, F. 2013. Pilot Study of Laser Induced Breakdown Spectroscopy for Tissue Differentiation by Monitoring the Plume Created during Laser Surgery - An Approach on A Feedback Laser Control Mechanism. Spectrochimica Acta Part B. 87: 175-181.

DOI: https://doi.org/10.1016/j.sab.2013.05.012.

[12] Wan, X., and Wang, P. 2015. Analysis of Heavy Metals in Organisms Based on an Optimized Quantitative LIBS. Optik. 126: 1930-1934.

DOI: https://doi.org/10.1016/j.ijleo.2015.05.039.

[13] Yueh, F., Zheng, H., Singh, J. P. and Burgess, S. 2009 Preliminary Evaluation of Laser-Induced Breakdown Spectroscopy for Tissue Classification. Spectrochimica Acta Part B 64: 1059-1067. DOI: https://doi.org/10.1016/j.sab.2009.07.025.

[14] Harun, H. A., and Zainal, R. 2018. Laser-induced Breakdown Spectroscopy Measurement for Liquids: Experimental Configurations and Sample Preparations. Journal of Nonlinear Optical Physics \& Materials. 27(2): 1850023

DOI: https://doi.org/10.1142/S0218863518500236

[15] Al-Adel, F. F., Dastageer, M. A., Gasmi, K., and Gondal, M. A. 2013. Optimization of a Laser Induced Breakdown Spectroscopy Method for the Analysis of Liquid Samples. Journal of Applied Spectroscopy. 80(5): 767-770. DOI: https://doi.org/10.1007/s10812-013-9839-8.

[16] Bellof, G., Most, E., and Pallauf, J. 2006. Concentration of $\mathrm{Ca}, \mathrm{P}, \mathrm{Mg}, \mathrm{Na}$ and $\mathrm{K}$ in Muscle, Fat and Bone Tissue of Lambs of the Breed German Merino Landsheep in the Course of the Growing Period. Journal of Animal Physiology and Animal Nutrition. 90: 385-393. DOl: https://doi.org/10.1111/j.1439-0396.2006.00610.x.

[17] Yu, K., Zhao, Y., Liu, F., and He, Y. 2016. Laser-Induced Breakdown Spectroscopy Coupled With Multivariate Chemometrics for Variety Discrimination of Soil. Scientific Reports. 6: 27574

DOI: https://doi.org/10.1038/srep27574.

[18] Porizka, P., Klus, J., Kepes, E., Prochazka, D., Hahn, D. W. and Kaiser, J. 2018. On the Utilization of Principal Component Analysis in Laser-Induced Breakdown Spectroscopy Data Analysis, A Review. Spectrochimica Acta Part B. 148: 65-82 DOI: https://doi.org/10.1016/j.sab.2018.05.030.

[19] Hanasil, N. S., Raja Ibrahim, R. K., Duralim, M., Sapingi, H. H. J., \& Mahdi, M. A. 2020. EXPRESS: Signal Enhancement Evaluation of Laser Induced Breakdown Spectroscopy of Extracted Animal Fats Using a Principal Component Analysis Approach. Applied Spectroscopy. DOI: https://doi.org/10.1177/0003702820915532. 